\title{
Volatiles in the HIMU mantle component and the efficiency of dehydration during subduction
}

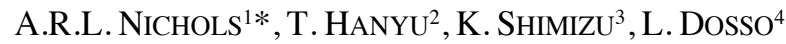 \\ ${ }^{1}$ School of Earth and Environment, University of \\ Canterbury, New Zealand (*correspondence: \\ alex.nichols@canterbury.ac.nz) \\ ${ }^{2}$ Volcanoes and Earth's Interior Research Center (VERC), \\ Japan Agency for Marine Earth Science and Technology \\ (JAMSTEC), Japan \\ ${ }^{3}$ Kochi Institute for Core Sample Research, JAMSTEC, \\ Japan \\ ${ }^{4}$ CNRS - IFREMER Ctr Brest, Plouzane, France
}

Pillow basalts have been collected from the flanks of Rurutu and Tubuai in the Austral Islands, South Pacific by submersible. Whole rock radiogenic isotope and trace element chemistry of these samples suggests that the basalts were generated from a HIMU mantle component derived from recycled ancient subducted oceanic crust that entrained and mixed with depleted asthenospheric mantle. Sixteen glassy rims from the same samples have been analysed for major (electron microprobe), trace (LA-ICP-MS), and volatile elements $\left(\mathrm{H}_{2} \mathrm{O}\right.$ and $\mathrm{CO}_{2}$ by FTIR spectroscopy, $\mathrm{S}$ and $\mathrm{Cl}$ by electron microprobe) to constrain the volatiles in the magma sources, the volatiles in HIMU and the efficiency of subduction-related volatile-loss in the HIMU component. $\mathrm{H}_{2} \mathrm{O}$ ranges from 0.62 to $2.44 \mathrm{wt} \%, \mathrm{~S} 612$ to $1889 \mathrm{ppm}, \mathrm{Cl} 151$ to $538 \mathrm{ppm}$, while $\mathrm{CO}_{2}$ is below detection ( $<20 \mathrm{ppm}$ ). The highest $\mathrm{H}_{2} \mathrm{O}$ contents may reflect late-stage hydration and are oversaturated at the depth of collection, the low $\mathrm{H}_{2} \mathrm{O}$ contents (11 samples 0.62-0.96 wt $\%$ ) are undersaturated, and there is a positive correlation between the $\mathrm{H}_{2} \mathrm{O}$ contents of all chips and their incompatible element concentrations. $\mathrm{Cl}$ also correlates strongly with incompatible elements, while $\mathrm{S}$ correlates positively with $\mathrm{FeO}$ and $\mathrm{Cu}$, but not with incompatible elements, suggesting sulfide saturation. Using $\mathrm{H}_{2} \mathrm{O} / \mathrm{Ce}$ and $\mathrm{Cl} / \mathrm{Nb}$ the Rurutu source contains $292 \mathrm{ppm} \mathrm{H}_{2} \mathrm{O}$ and $7 \mathrm{ppm} \mathrm{Cl}$, and the Tubuai source contains $215 \mathrm{ppm} \mathrm{H}_{2} \mathrm{O}$ and $3 \mathrm{ppm} \mathrm{Cl}$. Using the isotopic compositions to estimate the contribution from HIMU in the sources of Rurutu (11\% HIMU) and Tubuai ( $3 \%$ HIMU), the $\mathrm{H}_{2} \mathrm{O}$ content of the HIMU component is $1,714 \mathrm{ppm}$ in the Rurutu source, and 3,415 ppm in the Tubuai source. Thus, assuming oceanic crust entering a subduction zone contains 20,000-30,000 ppm $\mathrm{H}_{2} \mathrm{O}$, the HIMU component in the Rurutu source has been $\sim 91-94 \%$ dehydrated and $\sim 83-89 \%$ dehydrated in the Tubuai source. 